\title{
MODUS OPERANDI DAN PROBLEMATIKA PENANGGULANGAN TINDAK PIDANA PENIPUAN DARING
}

\author{
Anton Hendrik Samudra* \\ Fakultas Hukum, Universitas Surabaya \\ Jalan Raya Kalirungkut, Surabaya, Jawa Timur 60293
}

\begin{abstract}
Online fraud experienced by the society in general perspective, and the East Java community in particular. Victims hope that the perpetrator can be arrested, and the victim's loss got returned. Beside the technical constraints faced by law enforcement regarding privacy and data security regimes that also protect perpetrators, there is also problem in the rule of law. The norm specifically regulated in Article 28 paragraph (1) Law 11 of 2008 on Electronic Transaction Information (UU ITE) has a special restriction because of its consumer protection dimension. This article is a result of a research conducted regarding the profile of the modus operandi of online fraud in East Java and outlining the emerging legal problems. The research method used is juridical empiric and juridical normative, empiric juridical used to gather data, whereas juridical normative by literature study. The research findings are: it is necessity to reformulate the norms related to online fraud in the ITE Law because in its modus, there are cases of online fraud which not covered by Article 28 paragraph (1) of the ITE Law.
\end{abstract}

Keywords: deception, online, modus operandi, legal problems.

\section{Intisari}

Tindak pidana penipuan daring cukup banyak dialami masyarakat pada umumnya, dan masyarakat Jawa Timur pada khususnya. Korban sangat berharap pelakunya dapat ditangkap kemudian uang atau kerugian korban dikembalikan. Selain kendala teknis yang dialami penegak hukum dalam rezim privasi dan keamanan data yang juga melindungi pelaku, juga terdapat problematika dalam pengaturan norma hukum. Norma yang diatur secara khusus dalam Pasal 28 ayat (1) UU No. 11 Tahun 2008 tentang Informasi Transaksi Elektronik (UU ITE) memiliki batasan khusus karena dimensi perlindungan konsumennya. Tulisan berikut ini merupakan hasil penelitian tentang profil modus operandi tindak pidana penipuan daring di Jawa Timur, penormaannya terkait tindak pidana tersebut dan menguraikan problematika hukum yang muncul. Metode penelitan yang digunakan adalah yuridis empiris dan yuridis normatif, yuridis empiris dilakukan dengan pengambilan dan pengolahan data sedangkan yuridis normatif dengan cara studi kepustakaan. Temuan penelitian adalah perlunya reformulasi norma terkait penipuan daring dalam UU ITE karena dalam profil modusnya terdapat kasus penipuan daring yang tidak tercakup dalam Pasal 28 ayat (1) UU ITE.

Kata kunci: penipuan, daring, modus operandi, problematika hukum.

\section{Pokok Muatan}

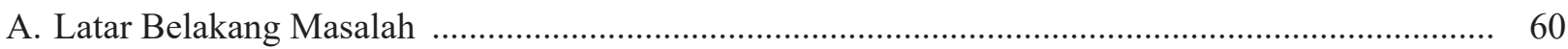

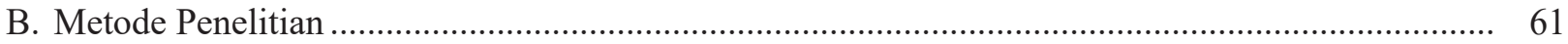

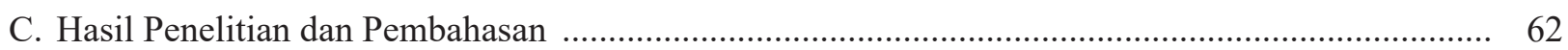

1. Modus Operandi Penipuan Daring yang Ditangani Polda Jawa Timur .................................... 62

2. Konstruksi Hukum dalam Rumusan Pasal dalam UU ITE dalam Menanggulangi

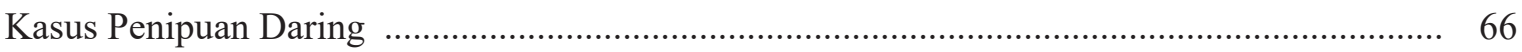

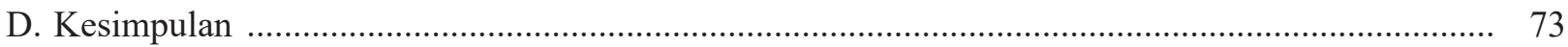

Alamat Korespondensi: antonhendriks@yahoo.com. 


\section{A. Latar Belakang Masalah}

Basis terjadinya transaksi adalah kesepakatan. Kesepakatan dalam transaksi daring tidak lagi dilakukan secara konvensional yang dipahami sebelumnya. Kesepakatan dalam transaksi daring dilakukan menggunakan medium berupa informasi dan/atau dokumen elektronik. Dalam perekonomian, transaksi memang diharapkan serba cepat. Semakin cepat transaksi dilakukan, semakin bagus pertumbuhan perekonomian, sehingga trendnya transaksi dilakukan secara elektronik. Bahkan sudah berkembang apa yang dinamakan dengan kontrak elektronik. Perkembangan teknologi keuangan juga merupakan pendorong majunya perekonomian nasional. Saat ini uang sudah bukan hanya berbentuk kertas dan logam, tetapi juga data atau informasi elektronik yang tertampil di telepon seluler, laptop/komputer, dsb. Terdapat pergeseran kebudayaan dalam menciptakan pasar. Pasar sudah tidak lagi berbentuk fisik, harus sewa atau beli lahan. Perkembangan sekarang ini, pasar bentuknya adalah sosial media, situs, blog, dan semacamnya. Pasar semacam ini dikenal dengan istilah e-commerce.

Belanja secara online atau daring sudah menjadi bagian dari masyarakat modern, karena menawarkan kemudahan dalam bertransaksi. Bahkan, hal ini sudah menjadi keniscayaan. Sudah banyak situs dan aplikasi belanja online yang dapat dioperasikan bahkan melalui telepon seluler. Selain itu media sosial juga banyak digunakan dalam melakukan kegiatan transaksi jual beli. Dengan adanya budaya bisnis baru ini, perekonomian Indonesia juga mendapatkan dampak positif darinya.

Eksistensi dan perkembangan teknologi selain bermanfaat bagi kehidupan manusia, juga memunculkan kejahatan dengan modus mutakhir. Penipuan daring memiliki karakteristik khusus yang berbeda dengan penipuan konvensional. Selain kekhususannya terletak pada media yang digunakan, penipuan daring tergolong sebagai faceless crime. Para pihak yang mengadakan transaksi tidak pernah bertemu tatap muka. Data hasil penelitian yang dilakukan pada tahun 2016-2017 tentang modus operandi penipuan menunjukkan bahwa terdapat modus-modus mutakhir tindak pidana penipuan.

Data yang disajikan oleh Kaspersky Lab dari survey yang dilakukan oleh B2B International tentang Consumer Security Risks 2016, ada 48\% konsumen menjadi target penipuan yang dirancang untuk menipu dan mendapat informasi sensitif yang digunakan untuk melakukan kejahatan. ${ }^{1}$ Untuk ancaman keuangan yang dialami konsumen, 6\% konsumen kehilangan uang karena penipuan daring. Rata-rata kerugian yang diderita tiap konsumen adalah USD 283 atau Rp. 3,6 juta. Hanya 54\% dari total konsumen yang uangnya dapat kembali utuh, sedangkan 23\% tidak berhasil mendapatkan uangnya kembali. ${ }^{2}$ Sedangkan empat persen dari konsumen menjadi korban kebocoran data dan kehilangan uang melalui organisasi keuangan dan tiga persen konsumen pemilik cryptocurrency (seperti BitCoin) atau e-money kecurian. Hampir separuh dari pengguna Internet mengalami ancaman keuangan selama periode survei 12 bulan, seperti menerima surel mencurigakan yang mengaku dari bank (22\%) atau situs ritel (15\%), dan permintaan data keuangan (11\%). ${ }^{3}$

Indonesia termasuk negara ke 9 terbesar pengguna ponsel pintar di dunia. Dikalkulasi terdapat 57.7 juta pengguna di 2014, dan 71.6 juta di tahun 2015, dan angka tersebut bertambah terus diestimasikan mencapai 100 juta di tahun 2017. Ponsel pintar merupakan gawai paling popular untuk mengakses internet (65.7 persen dari total populasi pengguna internet), diikuti komputer meja (52 persen dari total populasi pengguna internet), laptop (45,1 persen dari total populasi pengguna

\footnotetext{
Kaspersky Lab., "Consumer Security Risks Survey 2016: Connected But Not Protected”, https://press.kaspersky.com/files/2016/10/B2C_ survey 2016 report.pdf, diakses 16 Mei 2017.

Ibid.

Tempo online, "Penipuan Online di Indonesia Tertinggi", https://m.tempo.co/read/news/2016/05/30/172775347/penipuan-online-diindonesia-tertinggi, diakses tanggal 16 Mei 2017.
} 
internet), dan tablet (1.9 persen dari total populasi pengguna internet). ${ }^{4}$ Orang Indonesia termasuk rentan menjadi korban kejahatan daring. Masih dari data yang sama, ditunjukkan bahwa Indonesia adalah negara di mana 26\% konsumennya menjadi korban kejahatan daring. ${ }^{5}$

Tulisan ini ditujukan untuk membahas mengenai pengaturan penanggulangan tindak pidana penipuan dalam transaksi daring. Tulisan ini merupakan bagian dari hasil penelitian yang dilakukan di tahun 2016, sebagian yang lain telah dipresentasikan dalam Konferensi Internasional 'Tackling Financial Crime' yang diadakan oleh Universitas Surabaya, USDOJ dan Thammasat University Thailand, yang kemudian diterbitkan buku referensi mengenai penanggulangan kejahatan keuangan. Yang membedakan artikel ini dengan tulisan di buku tersebut adalah dalam tulisan ini lebih memfokuskan pada profil modus secara regional Jawa Timur serta narasi kualitatif yang lebih mendetail dalam profil modus operandinya serta problematika yang muncul pada pengaturannya. Dalam beberapa e-journal telah ada tulisan-tulisan yang terkait tindak pidana penipuan daring, tetapi tidak satupun mengkaji data kasus yang terjadi di Jawa Timur. Selain itu tulisan-tulisan tersebut lebih fokus di perlindungan hukum terhadap korban dan pertanggungjawaban pidana pelaku.

Berlandaskan pada latar belakang yang dijelaskan di atas, maka menarik untuk di kaji lebih lanjut dengan rumusan masalah yang dibahas antara lain mengenai (1) Bagaimana modus operandi penipuan daring dari laporan yang telah ditangani Reserse Kriminal Khusus Siber Polda Jatim? (2) Apakah konstruksi hukum dalam rumusan pasal dalam UU ITE sudah mencukupi untuk menanggulangi kasuspsenipuan daring?

\section{B. Metode Penelitian}

Metode penelitian yang digunakan adalah metode penelitian hukum yuridis normatif dilengkapi dengan hasil observasi dan wawancara narasumber. Kegiatan yang juga akan dilakukan adalah pengamatan di lokasi penelitian yaitu di Markas Kepolisian Daerah Jawa Timur, khususnya Reserse Kriminal Khusus Siber, kemudian wawancara narasumber yang adalah pejabat polisi terkait, dan analisis data, mulai dari dokumen laporan polisi sampai dengan berita acara pemeriksaan. Lokasi penelitian dipilih dan ditentukan selain daripada alasan proximity lokasi dengan penulis, juga mempertimbangkan keberadaan Direktorat Reserse Kriminal Khusus Siber, yang khusus menangani kejahatan siber yang termasuk salah satunya adalah tindak pidana penipuan daring, dan cakupan yurisdiksinya adalah provinsi Jawa Timur yang adalah salah satu provinsi yang sibuk dengan kegiatan transaksi jual-beli daring.

Terkait metode yuridis normatif, Ibrahim mengemukakan bahwa penelitian hukum yuridis normatif adalah penelitian yang difokuskan untuk mengkaji penerapan kaidah-kaidah atau normanorma dalam hukum positif. ${ }^{6}$ Penelitian ini dilakukan melalui studi pustaka atas peraturan perundangundangan yang terkait tindak pidana penipuan daring beserta doktrin-doktrin hukum yang terkait, melalui pendekatan peraturan perundang-undangan (statute approach), dan pendekatan konseptual (conceptual approach). ${ }^{7}$ Kedua pendekatan tersebut digunakan untuk menganalisis dan memberi pemecahan masalah (problem solving).

Pengumpulan bahan hukum dilakukan melalui penelusuran pustaka yang diawali dengan inventarisasi, klasifikasi, dan sistemasi bahan hukum. Untuk menganalisis, dilakukan deskripsi analisis atas bahan-bahan hukum yang

Anton Hendrik S, et al., 2017, Online Transaction Fraud Methods in Indonesia and the Norm of Deterrence: The Challenges and Obstacles dalam Elfina L. Sahetapy, et.al., Tackling Financial Crimes: Various International Perspectives, Genta Publishing, Yogyakarta, hal. $165-166$ Kaspersky Lab., Op.cit.

Johnny Ibrahim, 2005, Teori dan Metode Penelitian Hukum Normatif, Bayumedia, Malang, hlm. 240.

Peter M. Marzuki, 2005, Penelitian Hukum, Kencana, Jakarta, hlm. 97-137 
diawali dengan menelaah bahan-bahan hukum primer dengan menggunakan metode deduksi. Pembahasan dari aspek normatif dikedepankan mengingat penelitian ini adalah penelitian hukum. Untuk memperkuat pemberian dasar argumentasi dan membuat penelitian aplikatif dalam praktik penegakan hukum, perlu diperoleh data hasil survei dan wawancara terhadap informan kunci yang berkompeten, antara lain Pejabat Reserse Kriminal Khusus Siber Kepolisian Daerah Jawa Timur (Polda Jatim).

\section{Hasil Penelitian dan Pembahasan}

1. Modus Operandi Penipuan Daring yang Ditangani Polda Jawa Timur

Menurut data yang didapat di regional Jawa Timur, perkara penipuan daring yang masuk Polda Jawa Timur di tahun 2015 sebanyak 176 laporan, sedangkan di tahun 2016 kuartal pertama sebanyak 16 laporan. ${ }^{8}$ Dalam data tersebut, modus operandi paling populer dalam tindak pidana penipuan daring adalah penggunaan sarana iklan berbasis laman situs, yang pada umumnya dilanjutkan dengan korespondensi pesan singkat untuk melanjutkan rangkaian tipu muslihat dari pelaku untuk mendapatkan keuntungan secara tidak patut.

\section{Modus Penipuan Daring 2015}

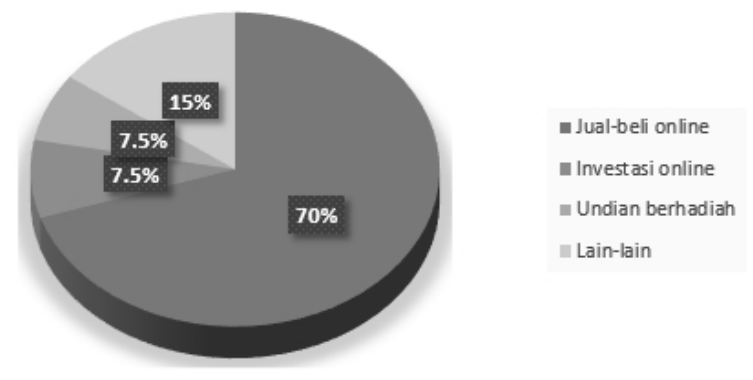

Grafik 1. Statistik Modus Penipuan Daring yang Dilaporkan ke Polda Jatim Tahun 2015

Data yang didapatkan dari penelitian, dari 176 laporan tindak pidana penipuan daring masuk Polda

$8 \quad$ Ibid., hlm. 22
Jatim di tahun 2015, sejumlah 60 kasus terselesaikan, sedangkan 116 kasus tidak terselesaikan dan sisanya masih dalam tahap penyelidikan dan penyidikan. Di tahun 2016 terdapat 29 laporan tindak pidana penipuan daring yang masuk Polda Jatim, yang pada saat penelitian dilakukan, kesemuanya masih dalam proses penyelidikan dan penyidikan.

Mengenai sarana yang digunakan, data tindak pidana penipuan daring untuk tahun 2015 adalah sebagai berikut:

\section{Tabel 1. Data Kasus Penipuan Daring yang} Dilaporkan ke Polda Jatim Tahun 2015

\begin{tabular}{|c|c|}
\hline Jenis Penipuan & $\begin{array}{c}\text { Jumlah Laporan } \\
\text { yang Masuk }\end{array}$ \\
\hline $\begin{array}{l}\text { 1. Web Fraud (Penipuan } \\
\text { dengan media Web/ } \\
\text { Website) }\end{array}$ & 108 Laporan \\
\hline $\begin{array}{l}\text { 2. Email Fraud (Penipuan } \\
\text { dengan media Email) }\end{array}$ & 10 Laporan \\
\hline $\begin{array}{l}\text { 3. Telephone Fraud } \\
\text { (Penipuan dengan media } \\
\text { Telepon) }\end{array}$ & 21 Laporan \\
\hline $\begin{array}{l}\text { 4. SMS Fraud (Penipuan } \\
\text { dengan media SMS) }\end{array}$ & 36 Laporan \\
\hline $\begin{array}{ll}\text { 5. } & \text { Credit Card Fraud } \\
\text { (Penipuan kartu kredit) }\end{array}$ & 1 Laporan \\
\hline $\begin{array}{l}\text { Total Laporan Tindak Pidana } \\
\text { Penipuan Daring yang Masuk }\end{array}$ & 176 Laporan \\
\hline $\begin{array}{c}\text { Sumber: Data Reskrimsus } \\
\text { Tahun, } 2015 .\end{array}$ & Siber Polda Jatim \\
\hline
\end{tabular}

Selain itu, data tindak pidana penipuan daring terkait sarana untuk tahun 2016.

\section{Modus Penipuan Daring 2016}

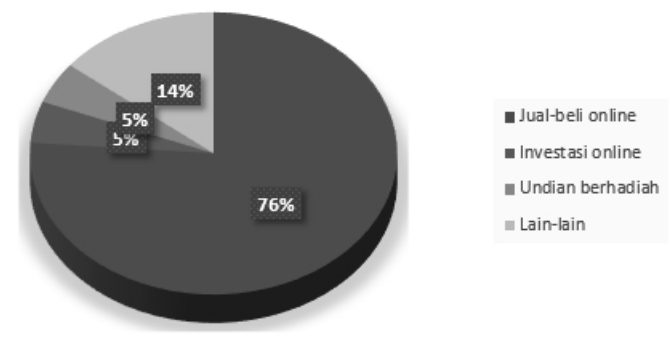

Grafik 2. Statistik Modus Penipuan Daring yang Dilaporkan ke Polda Jatim Tahun 2016 
Mengenai sarana yang digunakan, data tindak pidana penipuan daring untuk tahun 2016 adalah sebagai berikut:

Tabel 2. Data Kasus Penipuan Daring yang Dilaporkan ke Polda Jatim Tahun 2016

\begin{tabular}{llr}
\hline No & \multicolumn{1}{c}{ Jenis Penipuan } & \multicolumn{1}{c}{$\begin{array}{c}\text { Jumlah Laporan } \\
\text { yang Masuk }\end{array}$} \\
\hline 1. & Web Fraud (Penipuan \\
dengan media Web/ & 15 Laporan \\
& \\
\hline $\begin{array}{l}\text { Website) } \\
\text { 2. }\end{array}$ & Email Fraud (Penipuan \\
dengan media Email) & Laporan \\
\hline 3. & $\begin{array}{l}\text { Telephone Fraud } \\
\text { (Penipuan dengan media } \\
\text { Telepon) }\end{array}$ & 7 Laporan \\
\hline 4. & $\begin{array}{l}\text { SMS Fraud (Penipuan } \\
\text { dengan media SMS) }\end{array}$ \\
\hline 5. & $\begin{array}{l}\text { Credit Card Fraud } \\
\text { (Penipuan kartu kredit) }\end{array}$ \\
\hline $\begin{array}{l}\text { Total Laporan Tindak Pidana } \\
\text { Penipuan Daring yang Masuk }\end{array}$ & 0 Laporan \\
\hline
\end{tabular}

Sumber: Data Reskrimsus Siber Polda Jatim Tahun, 2016.

Terjadi penurunan laporan yang signifikan. Mengenai penyebab fenomena penurunan laporan ini tidak menjadi fokus dari tulisan ini. Dalam hal ini tulisan ini tidak membahas mengenai sebab penurunan tersebut, dan penelitian mengenai hal ini mungkin perlu diadakan tersendiri.

Penipuan menggunakan media laman situs jumlah laporannya mendominasi dibandingkan modus yang lain. Distribusi informasi menggunakan laman situs adalah hal yang sangat umum di era perdagangan daring. Membuat sebuah laman situs juga tergolong mudah, ada yang versi gratis dan ada juga yang berbayar. Laman situs versi gratis umum disebut dengan blog. Blog yang cukup popular digunakan pelaku penipuan daring adalah blogspot, karena pembuatannya yang relatif mudah. Salah satu contoh blog adalah pindadsenjata.blogspot. co.id, yang adalah website yang beriklan menjual senjata api tetapi menipu konsumennya dengan modus penipuan "non-delivery".

Laman Kaskus juga merupakan laman jualbeli yang sangat sering digunakan. Bahkan di Kaskus, pembeli dan penjual memiliki istilah khas untuk berkomunikasi. Di Kaskus, sebenarnya ada mekanisme verifikasi untuk kredibilitas penjual, namun tidak semua pencari informasi mengetahui hal ini. Hal inilah yang dimanfaatkan oleh pelaku penipuan untuk menjaring korban-korban yang kurang terinformasi dengan baik. Laman situs jual beli daring semakin banyak seiring berjalannya waktu, mulai dari yang lokal yaitu tokobagus. com yang berganti nama domain menjadi olx. co.id, bukalapak.com, tokopedia.com, dan yang internasional seperti Ebay, Amazon dan lainlainnya. Hampir semua memiliki cara preventif untuk mencegah penipuan namun tidak semua penggunanya mengerti dengan baik.

Berbelanja secara daring melalui cara selancar laman situs memberikan kenyamanan bagi kebanyakan penggunanya. Pembeli tidak perlu lagi repot-repot pergi ke pusat perbelanjaan dan berkeliling, cukup dengan belanja menggunakan laptop atau ponsel pintar, kemudian menghubungi penjual, transfer pembayaran, dan barang akan muncul di depan pintu kita diantar kurir/jasa pengiriman. Umumnya, setelah korban melihat informasi berupa iklan dalam website, mereka akan menghubungi penjual (yang adalah pelaku) secara personal menggunakan kontak yang dicantumkan penjual di website tersebut. ${ }^{10}$

Segala kegiatan transaksi daring dilakukan menggunakan teknologi informasi komunikasi, termasuk penawaran-penerimaan-kesepakatan. Bahkan semua itu dilakukan tanpa tatap muka. Mengingat karakteristik tindak pidana penipuan daring yang faceless, penyidik menemukan bahwa pelaku penipuan adalah orang yang menggunakan identitas palsu atau dapat dikatakan sebagai subyek

\footnotetext{
Modus "non-delivery" adalah korban penipuan tidak mendapatkan barang yang dibeli padahal sudah melakukan pembayaran melalui transfer bank.

10 Hasil profil dari kasus tindak pidana penipuan transaksi jual beli online yang dilaporkan ke Reskrimsus Siber Polda Jawa Timur.
} 
hukum fiktif, yang mengakibatkan kasus penipuan daring sulit diteruskan ke proses penuntutan. Oleh karena itu, keberadaan informasi elektronik dan/ atau dokumen elektronik memegang peranan penting sebagai alat bukti.

Metode penipuan yang lain adalah menggunakan metode pembobolan email yang digunakan perusahaan yang sedang berhubungan bisnis dengan perusahaan asing. Email perusahaan lokal diretas (hack), kemudian pelaku menggunakannya untuk mendapatkan uang dari perusahaan asing yang sedang bekerjasama dengan perusahaan lokal tersebut menggunakan rangkaian kata-kata bohong dan tipu muslihat. Email perusahaan yang diretas tersebut digunakan pelaku untuk membelokkan transaksi yang seharusnya dibayarkan ke rekening perusahaan lokal ke rekening peretas (hacker). Perusahaan asing baru sadar adanya penipuan setelah mereka berkomunikasi langsung dengan perusahaan lokal rekanan mereka. ${ }^{11}$

Kasus-kasus yang terungkap beberapa di antaranya diketahui bahwa pelaku kejahatan siber biasanya terlebih dulu memantau aktivitas email perusahaan yang diincar. Mereka baru beraksi setelah mengetahui perusahaan itu sedang mengadakan kerjasama bisnis dengan perusahaan asing. Perusahaan lokal biasanya terlebih dulu mengadakan pertemuan dengan perusahaan asing dalam menjalin komunikasi bisnis. Setelah ada kesepakatan, komunikasi dilanjutkan lewat email. Saat itulah, pelaku mulai membajak email perusahaan. Kemudian mereka menagih pembayaran lewat rekening lain dengan alasan rekening perusahaan sedang bermasalah dan sebagainya. Pertengahan tahun 2014, Polda Jatim berhasil mengungkap kasus kejahatan siber yang melibatkan dua peretas asal Indonesia dan Nigeria yang berhasil membobol email sebuah perusahaan di Surabaya. Mereka membelokkan pembayaran yang nilainya mencapai $\mathrm{Rp}$ 1,5 miliar dari perusahaan di Jepang ke perusahaan tersebut.

Modus penipuan yang menggunakan sarana telepon ada yang berdiri sendiri dan ada yang merupakan kelanjutan dari modus penipuan menggunakan sarana website. Namun umumnya keduanya menggunakan nama atau martabat palsu. Salah satu contoh penipuan menggunakan sarana telepon adalah pelaku mengaku sebagai keluarga dan meminta pertolongan karena kecelakaan atau tertangkap polisi agar mentransfer sejumlah uang. Contoh yang merupakan kelanjutan dari modus penipuan menggunakan sarana website adalah pelaku atau rekannya menelepon mengaku sebagai petugas bea cukai kemudian mengatakan bahwa barang yang dikirim sedang disita oleh bea cukai dan harus ditebus jika ingin dikirimkan. Ada juga yang menggunakan cara meminta pembeli sebagai korban untuk pergi ke ATM (Automated Teller Machine) dan akan dibimbing di sana untuk melakukan transaksi, namun berujung pada korban mentransferkan sejumlah uang ke rekening yang dikehendaki pelaku.

Penipuan menggunakan sarana SMS (short message services) biasa dilakukan pelaku dengan cara mengirim SMS kepada penerima acak dengan sistem send-to-many (penerima pesan lebih dari satu) atau sejenis broadcast message. Kemudian pelaku menunggu beberapa respon yang kemudian ditindaklanjuti dengan kebohongan dan tipu muslihat agar korban mentransfer sejumlah uang.

Terdapat kasus seseorang yang mengaku sebagai calon pembeli yang menghubungi penjual produk atau penyedia jasa - karena melihat iklan yang diposting oleh penjual atau penyedia, yang kemudian yang mengaku calon pembeli menginstruksikan banyak hal melalui telepon kepada penjual produk atau penyedia jasa, untuk pergi ke ATM. Namun instruksi tersebut pada intinya berujung pada penjual mentransferkan sejumlah uang melalui ATM ke rekening yang mengaku calon pembeli tadi. Untuk kasus penipuan menggunakan sarana/media telepon baru dapat ditangani Reskrimsus Siber Polda Jatim apabila ada alat bukti berupa rekaman telepon yang dapat

11 Korespondensi dan wawancara dengan AKBP Wahyu Setya, Panit II Reskrimsus Siber Polda Jawa Timur. 
dijadikan sebagai alat bukti berupa informasi elektronik. Jika alat bukti berupa rekaman tersebut tidak ada, maka penanganan akan dilimpahkan ke Reserse Kriminal Umum (Reskrimum) untuk ditangani sebagai kasus penipuan konvensional. Terdapat juga kasus penggunaan kartu kredit secara melawan hukum dan tanpa hak. Dalam hal ini pelaku menggunakan metode penipuan untuk mendapatkan informasi detil mengenai kartu kredit, sehingga kemudian kartu kredit yang dimaksud dapat digunakan oleh pelaku untuk berbelanja. Caranya adalah dengan memotret kartu kredit yang dimaksud, baik sisi depan maupun belakang. Sisi depan untuk mendapatkan nomor kartu kreditnya, sedangkan sisi belakang untuk mendapatkan nomor CVV yang berfungsi sebagai otorisasi penggunaan kartu kredit. Informasi terakhir yang dibutuhkan pelaku adalah alamat penagihan (billing address), setelah itu pelaku dapat menggunakan kartu kredit korban untuk berbelanja daring.

Dari data-data tersebut di atas dapat dipahami dua hal, yaitu bahwa penipuan daring terbagi menjadi dua, yaitu penipuan konvensional dengan media teknologi informasi komunikasi daring sebagai alat komunikasi untuk eksekusi penipuan, dan penipuan yang pada hakikatnya mencuri dana dengan cara mencuri data rahasia atau security credentials.

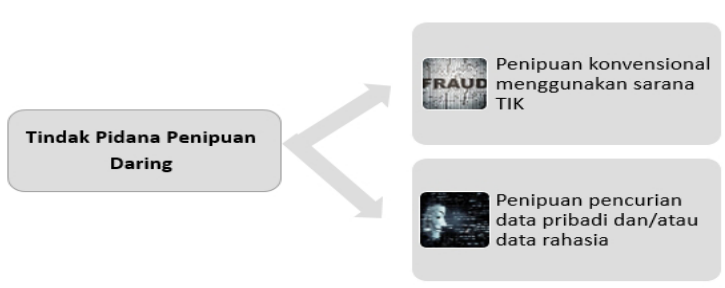

\section{Gambar 1. Pembagian Tindak Pidana Penipuan Daring}

Sedangkan yang kedua, dapat disimpulkan bahwa profil dari modus operandi tindak pidana penipuan daring yang dilaporkan ke Reskrimsus Polda Jatim terbagi menjadi:

a. Penipuan yang dilakukan penjual produk atau penyedia jasa kepada konsumen b. Penipuan menggunakan nama palsu atau martabat palsu dengan akses ilegal terlebih dahulu

c. Penipuan menggunakan nama palsu atau martabat palsu, di luar dari hubungan produsen - konsumen

d. Penipuan oleh calon pembeli kepada penjual produk atau penyedia jasa

Untuk skema profil modus operandi huruf a di atas, dapat digambarkan sebagai berikut:

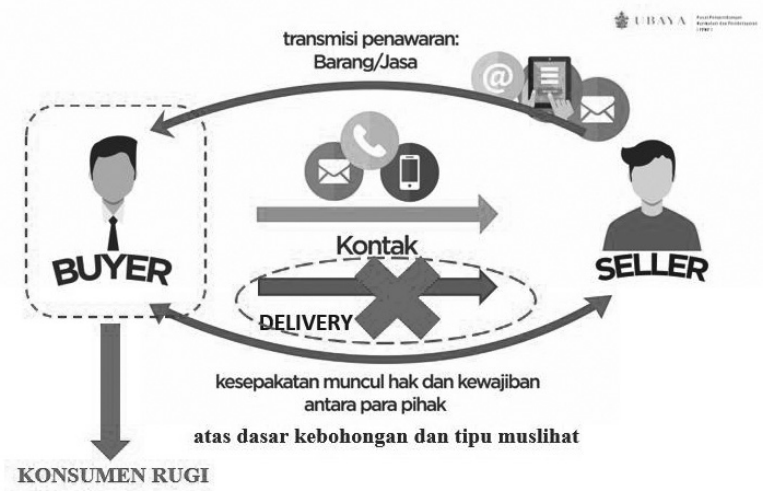

Gambar 2. Ilustrasi Salah Satu Modus Operandi Tindak Pidana Penipuan Daring

Untuk modus operandi yang profilnya dijelaskan pada huruf a dan pada grafik 4 di atas, dapat diterapkan Pasal 28 ayat (1) UU ITE jo. Pasal 45A ayat (1) Perubahan UU ITE. Setiap proses yang dilakukan dalam profil modusnya mencocoki setiap unsur pasal dalam Pasal 28 ayat (1) UU ITE jo. Pasal 45A ayat (1) Perubahan UU ITE, yaitu korban merupakan konsumen, terdapat berita bohong yang mengakibatkan kerugian konsumen, berita bohong tersebut disebarkan atau disampaikan menggunakan transmisi, distribusi, dan/atau dapat diaksesnya suatu informasi elektronik dan/atau dokumen elektronik. Mengenai analisis proposisi dalam unsur pasal lebih jauh terdapat pada pembahasan konstruksi hukum di bawah.

Untuk modus operandi yang disebutkan dalam huruf $b$, secara profil dapat dikenakan perbarengan (konkursus). Untuk akses ilegalnya dapat dikenakan Pasal 30 jo. Pasal 46 UU ITE, sedangkan untuk penipuannya apabila merugikan konsumen dapat diancamkan pula Pasal 28 ayat 
(1) UU ITE jo. Pasal 45A ayat (1) Perubahan UU ITE, atau apabila korbannya selain konsumen dapat diancamkan Pasal 378 KUHP.

Sedangkan untuk skema profil modus operandi huruf $\mathrm{c}$ dan $\mathrm{d}$ tersebut di atas, dapat digambarkan melalui profil kasusnya sebagai berikut:

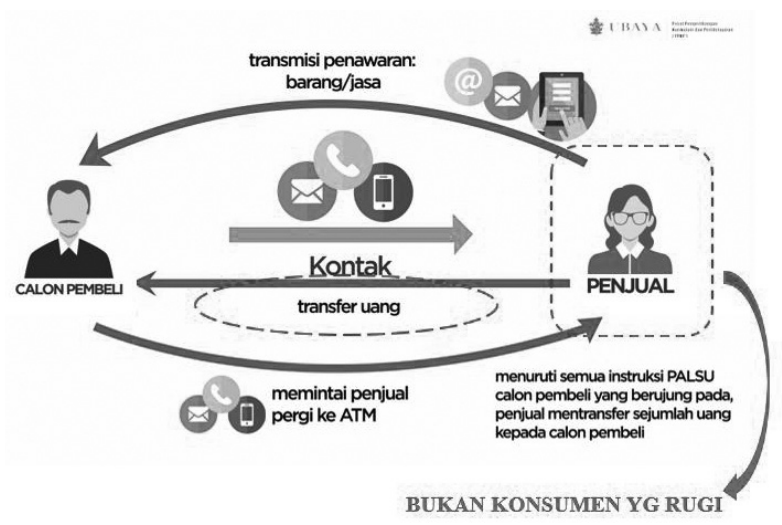

Untuk profil modus operandi yang disebutkan pada huruf $\mathrm{c}$ dan $\mathrm{d}$ serta yang tergambar di grafik 5 , UU ITE tidak dapat diterapkan karena jelas dalam Pasal 28 ayat (1) UU ITE menentukan lingkup berlakunya adalah melindungi konsumen yang menjadi korban. Untuk profil tersebut di atas, korbannya bukanlah konsumen. Dalam hal ini ketentuan hukum pidana yang dapat diterapkan adalah Pasal 378 KUHP dan penyidik yang memiliki kewenangan menangani bukanlah Reskrimsus Siber, melainkan Reskrimum.

2. Konstruksi Hukum dalam Rumusan Pasal dalam UU ITE dalam Menanggulangi Kasus Penipuan Daring

\section{a. Pasal 28 ayat (1) UU ITE sebagai \\ Pasal yang Secara Implementatif Digunakan untuk Pemberantasan Tindak Pidana Penipuan Daring}

Seiring perkembangan jaman, dalam keadaan tertentu KUHP tidak dapat menanggulangi permasalahan di masyarakat secara adil. Hubungan-hubungan kemasyarakatan yang sudah berkembang dengan adanya teknologi informasi perlu diatur. Menurut Roeslan Saleh, pemerintah melalui hukum dapat memengaruhi masyarakat, dan alatnya tersebut adalah hukum pidana. ${ }^{12}$ Dalam hal ini dilihat melalui tindakan Pemerintah dan DPR akhirnya membuat undang-undang khusus yang mengatur Informasi dan Transaksi Elektronik, yaitu UU ITE.

Indonesia menganut sistem kodifikasi terbuka, yang memungkinkan aturan hukum pidana khusus berada di luar KUHP. Mengingat modus, dan kecanggihan tindak pidana yang berkembang, serta ancaman sanksi pidana yang perlu disesuaikan konteks zaman ini membuat hukum pidana memiliki ketentuan di luar KUHP. Misalnya dalam transaksi jual beli daring, umumnya kesepakatan dilakukan tanpa bertemu secara fisik. Kemudian penjual/penyedia jasa memberitahukan rekening bank dan nama pemegang rekening ke konsumen, dan penjual/penyedia jasa menunggu sampai sejumlah uang yang disepakati ditransfer ke rekening mereka oleh konsumen.

\section{Tabel 3. Aturan Hukum Pidana Materiil}

\begin{tabular}{ll}
\hline \multicolumn{2}{c}{ Aturan Hukum Pidana Materiil } \\
\hline \multicolumn{1}{c}{ Umum } & \multicolumn{1}{c}{ Khusus } \\
\hline KUHP & Undang-undang Tindak Pidana \\
Buku kesatu & Khusus \\
${$\cline { 2 - 2 }$} }$ & $\begin{array}{l}\text { Undang-undang lain di luar } \\
\text { Buku ketiga }\end{array}$ \\
& $\begin{array}{l}\text { KUHP yang memuat ketentuan } \\
\text { pidana }\end{array}$ \\
\hline
\end{tabular}

Sumber: Diolah oleh Penulis, 2018.

Undang-undang Nomor 11 Tahun 2008 Tentang Informasi dan Transaksi Elektronik (Lembaran Negara RI Tahun 2008 Nomor 58, Tambahan Lembaran Negara RI Nomor 4843), yang untuk selanjutnya

12 Roeslan Saleh, 1981, Beberapa Asas-asas Hukum Pidana dalam Perspektif, Aksara Baru, Jakarta, hlm. 53. 
disebut UU ITE muncul di masanya dengan mendeklarasikan dirinya sebagai rezim hukum baru. ${ }^{13}$ Yang kemudian UU ini diubah dengan Undang-undang No. 19 Tahun 2016 Tentang Perubahan Atas Undang-undang Nomor 11 Tahun 2008 Tentang Informasi dan Transaksi Elektronik (Lembaran Negara RI Tahun 2016 Nomor 251, Tambahan Lembaran Negara RI Nomor 5952) yang selanjutnya disebut Perubahan UU ITE.

UU ITE tidak ada pengaturan yang secara spesifik mengenai penipuan. Dalam hal ini dapat dilihat dari tidak adanya penggunaan proposisi 'penipuan' di dalam pasal-pasalnya. Tetapi ada pengaturan mengenai larangan penyebaran berita bohong yang mengakibatkan kerugian konsumen, yaitu dalam Pasal 28 ayat (1), yang kental sekali dimensi tindak pidana penipuan dan perlindungan terhadap konsumen.

Melihat dari pengelompokan pengaturan dalam pasal-pasal di UU ITE, Pasal 28 ayat (1) disandingkan dengan ayat (2) yang mengatur tentang penyebaran konten ujaran kebencian terhadap SARA tertentu, yang jika dilihat dari sifatnya merupakan perlindungan terhadap ketertiban umum. Oleh karenanya, besar kemungkinan bahwa pengaturan ayat (1) juga perlindungan tehadap ketertiban umum, namun sayangnya kejelasan terhadap hal ini tidak ditemukan dalam naskah akademik pembentukan UU ITE, sehingga ini merupakan hasil analisa yang sifatnya hipotetikal, yang mungkin perlu diadakan penelitian tersendiri untuk memecahkannya.

Mengenai penjelasan di alinea sebelumnya, contoh kasus yang sangat relevan tentang perlindungan ketertiban umum dari penyebaran berita bohong terjadi di tahun 2008. Di tahun tersebut pernah terjadi kasus penyebaran surel tentang likuiditas sejumlah bank di Indonesia. Salah satu sales Bahana Securities mengirimkan surel dengan konten sebagai berikut:

"Market news stated that several lndo bank is having a liquidty problem and fail to complete interbank transaction. These Indo banks include: Bank Panin (PNBN), Bank Bukopin (BBKP), Bank Arta Graha (INPC): Bank CIC (BCIC) dan Bank Victoria (BVIC). We will keep you updated' ${ }^{14}$ (Terjemahan bebas: Berita pasar mengabarkan bahwa beberapa bank di lndonesia mendapat masalah likuiditas dan kegagalan dalam menyelesaikan transaksi antar bank. Bank tersebut diantaranya: Bank Panin, Bank Bukopin, Bank Arta Graha, Bank CIC, dan bank Victoria)"

Meskipun demikian, bukan berarti Pasal 28 ayat (1) UU ITE tidak dapat diterapkan manakala yang dirugikan adalah konsumen yang sifatnya individual. Mengingat penerapan pasal dapat digunakan metode penafsiran yang tidak hanya mengacu pada kehendak pembentuk undang-undang saja, asalkan tidak melanggar kaidah-kaidah penafsiran hukum pidana.

Pasal 28 ayat (1) UU ITE mengatur: "Setiap orang dengan sengaja dan tanpa hak menyebarkan berita bohong dan menyesatkan yang mengakibatkan kerugian konsumen dalam Transaksi Elektronik." Ancaman pidananya terdapat di Pasal 45A ayat (1) Perubahan UU ITE: "Setiap Orang yang dengan sengaja dan tanpa hak menyebarkan berita bohong dan menyesatkan yang mengakibatkan kerugian konsumen dalam Transaksi Elektronik sebagaimana dimaksud dalam Pasal 28 ayat (1) dipidana dengan pidana penjara paling lama 6 (enam) tahun dan/atau denda paling banyak Rp1.000.000.000,00 (satu miliar rupiah). 
- Inti perbuatan yang dilarang dalam Pasal 28 ayat (1) adalah:Sengaja dan tanpa hak;

- menyebarkan berita bohong dan menyesatkan; dan

- $\quad$ yang mengakibatkan kerugian konsumen dalam transaksi elektronik.

Pasal tersebut sama sekali tidak menggunakan proposisi 'penipuan'. Dari pembahasan Naskah RUU ITE, baik di rapat kerja maupun rapat dengar pendapat yang diselenggarakan DPR RI, kebanyakan membahas perlindungan dari penipuan namun konteksnya lebih banyak kepada nasabah, undian berhadiah, penipuan kartu kredit, dan penipuan multi-level marketing. Sejatinya, dalam tataran awam, aturan ini erat kaitannya dengan hoax. Dalam hal ini dapat dilihat karena proposisi yang digunakan dalam Pasal 28 ayat (1) UU ITE adalah 'berita bohong dan menyesatkan'. Chazawi menjelaskan mengenai 'berita bohong', adalah berita yang isinya tidak sesuai dengan kebenaran yang sesungguhnya (materiële waarheid). ${ }^{15}$ Lebih lanjut, dijelaskan bahwa 'menyebarkan' maksudnya menyampaikan (berita bohong) pada khalayak umum, dalam hal ini melalui media konvergensi telematika. ${ }^{16}$ Kemudian mengenai 'menyesatkan' berkaitan dengan berita bohong yang disebarkan, yang dapat memperdaya orang. Sifat memerdaya dari isi berita bohong yang disebarkan menyesatkan umum, sehingga menimbulkan akibat konstitutif berupa kerugian konsumen pada transaksi elektronik. ${ }^{17}$

Selain itu pasal ini erat sekali kaitannya denganperlindungankonsumen.Perlindungan yang diberikan pasal ini hanyalah kepada si yang merugi memiliki kedudukan sebagai konsumen. Secara a contrario, manakala yang mengalami kerugian tidak memiliki kedudukan sebagai konsumen atau berada di luar hubungan produsen - konsumen, pasal ini tidak dapat dikenakan. Sebenarnya tidak ada hubungan langsung antara UU ITE dengan Undang-undang No. 8 Tahun 1999 Tentang Perlindungan Konsumen (UU Perlindungan Konsumen). UU Perlindungan Konsumen lebih mengatur kewajiban dan larangan bagi pelaku usaha dalam rangka melindungi hak-hak konsumen. Larangan dan ancaman pidana yang diatur dalam UU Perlindungan Konsumen bukan yang terkait langsung dengan penipuan. Namun manakala pelaku usaha tidak memenuhi kewajiban "administratif" dan melanggar larangan, dapat dikenakan ketentuan pidana yang diancamkan dalam undang-undang tersebut.

Kembali ke UU ITE, tidak dijelaskan mengapa pembentuk undang-undang tidak menggunakan proposisi "penipuan" pada Pasal 28 ayat (1). Padahal dalam Naskah Akademik RUU ITE jelas disebutkan urgensi dan kepekaan pembentuk undang-undang terhadap penipuan menggunakan media informasi elektronik dan/atau dokumen elektronik. ${ }^{18}$ Namun lebih lanjut Naskah Akademik RUU ITE membatasi bahwa kejahatan dalam perdagangan elektronik (e-commerce) hanya penipuan lelang online, penipuan pemasaran berjenjang online, dan penipuan kartu kredit. ${ }^{19}$ Namun sayangnya, dalam draft awal RUU sekalipun hal tersebut tidak disebutkan mengenai penipuan itu. Pengaturan terkait ini baru muncul seperti yang tercantum dalam UU ITE dalam draft akhir naskah RUU, yaitu menggunakan

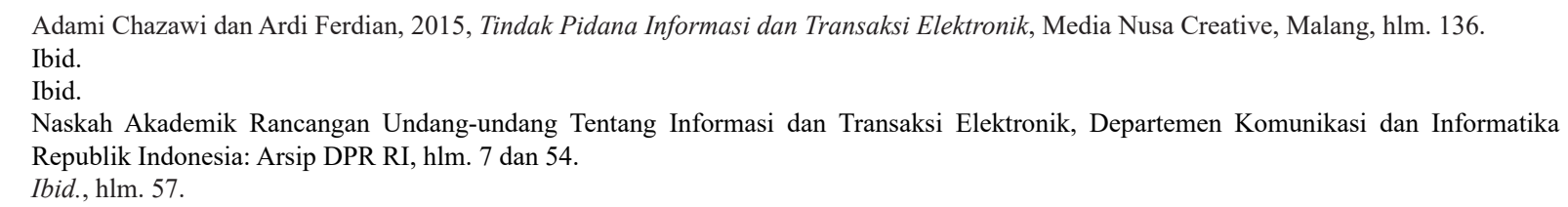


frasa "berita bohong dan menyesatkan yang mengakibatkan kerugian konsumen dalam transaksi elektronik".

Keberadaan 'kerugian konsumen' sebagai akibat dari perbuatan merupakan syarat mutlak terpenuhinya unsur pasal ini. Mengenai rumusan delik formil dan delik materiil, Hiariej menjelaskan dengan menyederhanakan bahwa delik formil adalah delik yang menitikberatkan pada tindakan, sedangkan delik materiil adalah delik yang menitik beratkan pada akibat. ${ }^{20}$ Akibat kerugian inilah yang juga mengindikasikan bahwa aturan ini termasuk delik materiil. Perlu dipahami juga bahwa harus ada hubungan kausal antara akibat dengan perbuatan, yaitu kerugian konsumen dengan berita bohong yang disebarkan. Proposisi ini juga menunjukkan bahwa pengaturannya kental akan dimensi perlindungan konsumen. Mengenai syarat adanya kerugian konsumen, berbeda jika dibandingkan dengan Pasal 378 KUHP, Pasal 378 KUHP mensyaratkan maksud perbuatan adalah untuk menguntungkan si pelaku atau orang lain. Dalam Arrest Hoge Raad 27 Mei 1935, tentang Pasal 378 ini, dijelaskan bahwa tidak perlu perbuatan tersebut telah menyebabkan timbulnya kerugian bagi orang lain dan hakim tidak perlu memastikan siapa yang telah dirugikan. ${ }^{21}$ Rumusan delik antara Pasal 28 ayat (1) UU ITE jo. Pasal 45A ayat (1) Perubahan UU ITE dan Pasal 378 KUHP adalah sama-sama delik materiil, namun ada perbedaan akibat yang disyaratkan untuk terpenuhinya pengenaan pasal.

Proposisi yang digunakan Pasal 28 ayat (1) UU ITE bukanlah 'penipuan' sebagaimana Pasal 378 KUHP mengkualifikasi tindak pidana yang dilarangnya, melainkan menggunakan proposisi 'berita bohong'. Proposisi inipun tidak dijelaskan secara lebih rinci dalam UU ITE. Pembentuk undangundang memandang istilah ini adalah istilah yang umum untuk dipahami. Dalam KUHP, proposisi 'berita bohong' digunakan dalam Pasal 390 KUHP dalam KUHP terjemahan Lamintang.

\section{b. Hubungan Pasal 28 ayat (1) UU ITE dengan Pengaturan Tindak Pidana Penipuan di KUHP}

Perlindungan terhadap harta kekayaan merupakan salah satu kepentingan hukum. Hak atas kebendaan merupakan hak yang dilindungi oleh hukum, bahkan konsitusi. ${ }^{22}$ Salah satu bentuk kejahatan terhadap harta benda yang dilarang dan diancam pidana adalah tindak pidana penipuan. Hal ini diatur dalam Bab XXV Buku ke-2 Kitab Undangundang Hukum Pidana (KUHP), yang tindak pidana penipuan pada pokoknya diatur dalam Pasal 378.

"Barang siapa dengan maksud untuk menguntungkan diri sendiri atau orang lain secara melawan hukum, dengan memakai nama palsu atau martabat palsu, dengan tipu muslihat, ataupun rangkaian kebohongan, menggerakkan orang lain untuk menyerahkan barang sesuatu kepadanya, atau supaya memberi hutang maupun menghapuskan piutang diancam karena penipuan dengan pidana penjara paling lama empat tahun."

Pasal ini menunjukkan bahwa pelaku penipuan ada maksud untuk menguntungkan diri sendiri dan atau orang lain, yang berarti jenis kesengajaannya merupakan kesengajaan sebagai maksud. Dalam hal ini, hakim tidak mensyaratkan untuk membuktikan siapa yang mengalami kerugian, cukup membuktikan

\footnotetext{
Eddy O.S. Hiariej, 2016, Prinsip-Prinsip Hukum Pidana, Edisi Revisi, Cahaya Atma Pustaka, Yogyakarta, hlm. 136.

Arrest H.R. 27 Mei 1935, N.J. 1936, 51, W. 12944 dalam P.A.F. Lamintang dan Djisman Samosir, 1990, Hukum Pidana Indonesia, Bandung, Sinar Baru, hal. 231 (P.A.F. Lamintang dan Djisman Samosir I).

Vide Pasal 28G ayat (1) Undang-undang Dasar Negara Republik Indonesia Tahun 1945.
} 
keberadaan maksud tersebut tadi. Anasir 'secara melawan hukum' dicantumkan sebagai unsur pasal, yang berarti unsur ini harus dibuktikan agar pelaku dapat dikenakan pasal ini. Melawan hukum di sini oleh Andi Hamzah menerangkan bahwa pelaku tidak memiliki hak untuk menikmati keuntungan tersebut. $^{23}$

Mengenai sarana penipuan, van Bemmelen menyatakan bahwa pembuat undang-undang memberikan limitasi, yaitu:

a. Memakai nama palsu, atau

b. Memakai martabat palsu,

c. Tipu muslihat,

d. Rangkaian kebohongan. ${ }^{24}$

Senada dengan van Bemmelen, R. Soesilo menyatakan tindakan pembujukan yang dilakukan penipu memakai:

a. Nama palsu atau keadaan palsu atau

b. Akal cerdik (tipu muslihat) atau

c. Karangan perkataan bohong. ${ }^{25}$

Nama palsu misalnya pelaku menggunakan nama yang dikenal baik atau disegani oleh korban. Lamintang menjelaskan bahwa nama palsu ini haruslah berupa nama orang, bisa jadi nama yang bukan namanya pelaku sendiri, atau sebuah nama yang tak seorangpun yang mempergunakannya, atau nama pelaku sendiri tetapi tidak diketahui oleh umum yang dilanjutkan dengan tipu muslihat. ${ }^{26}$ Sedangkan martabat palsu atau keadaan palsu atau sifat palsu tidaklah harus berupa jabatan, pangkat ataupun suatu pekerjaan resmi, misalnya mengaku sebagai pemuka agama atau pejabat pemerintah.
Mengatakan bahwa "berada dalam keadaan tertentu" di mana pelaku mengaku memiliki hak-hak tertentu, misalnya mengatakan bahwa dirinya adalah saudara atau teman baik dari seorang pejabat tertentu sehingga ia memiliki prioritas-prioritas tertentu padahal hal itu tidak benar. ${ }^{27}$

Mengenai tipu muslihat misalkan memberi janji atau menerangkan keadaan prospektif yang akan didapatkan oleh korban, dengan rangkaian kebohongan yang diceritakan, misalnya mengaku teman baik walikota dan sedang mengadakan arisan dengan keuntungan menarik berupa mobil. Tindakan pembujukan tersebut pada intinya ditujukan untuk menggerakkan korban menyerahkan barang sesuatu kepada pelaku, yang korbannya tidak akan menyerahkan barang sesuatu yang dimaksud jika korban mengetahui keadaan yang sesungguhnya. ${ }^{28}$ 'Menggerakkan' ini artinya pelaku menghendaki orang yang ditipu tergerak untuk menyerahkan sesuatu barang $^{29}$ kepadanya. Manakala tindakan tipu muslihat dan/atau rangkaian kebohongan tidak membuat orang lain menyerahkan barang sesuatu, maka pasal ini tidak dapat dikenakan. Hoge Raad pernah menyatakan bahwa untuk selesainya kejahatan ini diperlukan tindakan dari orang lain selain dari pelaku berupa penyerahan barang sesuatu. Apabila perbuatan pelaku tidak diikuti dengan tindakan penyerahan barang ${ }^{30}$, maka disini terdapat suatu 'permulaan tindakan pelaksanaan', dan bilamana kejahatan yang dimaksudkan tidak selesai disebabkan oleh pihak lain yang tidak mau melaksanakan per-

\footnotetext{
Arrest Hoge Raad tahun 1911 dalam Andi Hamzah, 2015, Delik-delik Tertentu (Speciale Delicten) di Dalam KUHP, Edisi Kedua, Sinar Grafika,, Jakarta, hlm. 100.

J.M. van Bemmelen, Op.cit., 1986, hlm. 146.

R. Soesilo, 1996, Kitab Undang-undang Hukum Pidana; Serta Komentar-komentarnya Lengkap Pasal Demi Pasal, Politeia, Bogor, hlm. 261. P.A.F. Lamintang dan Djisman Samosir I, Op.cit., hlm. 230.

29 Yang dimaksud dengan 'barang' merupakan sesuatu yang bentuknya tangible maupun intangible yang memiliki nilai ekonomi, misalnya uang atau listrik.

30 Menurut Arrest Hoge Raad 23 Maret 1931, untuk adanya penyerahan suatu barang disyaratkan adanya lepasnya kekuasaan seseorang atas barang tetapi tidak perlu jatuh dalam kekuasaan orang yang lain.
} 
buatan yang diharapkan oleh pelaku, maka terdapat suatu percobaan untuk melakukan tindak pidana penipuan. ${ }^{31}$

Sebagaimana telah disebutkan di atas bahwa proposisi 'berita bohong' digunakan dalam Pasal 390 KUHP. Berikut ini isi pasalnya:

"Barangsiapa dengan maksud untuk menguntungkan diri sendiri atau orang lain, dengan melawan hak, menyiarkan berita bohong untuk menaikan atau menurunkan harga barang-barang kebutuhan, dana-dana dan surat-surat berharga, dihukum dengan hukuman penjara selama-lamanya dua tahun delapan bulan."

Berdasar ketentuan Pasal 390 KUHP tersebut, Lamintang mengkualifikasikannya menjadi beberapa unsur yakni: ${ }^{32}$

a. Unsur-unsur obyektif:

i. Menyiarkan berita bohong atau een logenachtig bericht verspreiden.

ii. Menaikkan atau menurunkan atau doen stijgen of dalen.

iii. Harga kebutuhan, danadana dan surat-surat berharga atau koopwaren, fondsen en gelswaardige papieren.

b. Unsur-unsur subyektif:

i. $\quad$ Dengan maksud atau met het oogmerk

ii. Untuk menguntungkan diri sendiri atau orang lain atau om zich of een ander te bevoordelen

c. Secara melawan hak atau wederrechtlijk

Lamintang menyatakan secara jelas bahwa yang dilarang dalam Pasal 390 KUHP adalah perbuatan "menyiarkan berita bohong". Namun hal tersebut belum dapat menjadi hal yang dapat dikenakan hukuman. Lebih lanjut Lamintang menyatakan bahwa berita bohong itu haruslah bertujuan untuk menaikkan atau menurunkan harga, dana atau nilai surat berharga. ${ }^{33}$ Walaupun usaha untuk mempengaruhi harga di pasaran itu mempunyai berbagai maksud, namun batasannya jelas pada maksud menguntungkan diri sendiri atau orang lain. ${ }^{34}$

Dalam ketentuan Pasal 390 KUHP ini, unsur opzet nya adalah opzet als oogmerk sehingga semua perbuatan yang dilakukan oleh pelaku dimaksudkan untuk memperoleh keuntungan diri sendiri maupun orang lain secara melawan hak. Dengan mengacu pada yurisprudensi dalam Arrest Hoge Raad 12 Juni 1991 dinyatakan bahwa suatu berita bohong tidak cukup semata-mata merupakan pemberitaan yang tidak benar, tetapi haruslah disertai dengan suatu pengharapan.

Sejalan dengan itu, R. Soesilo juga menyatakan bahwa:

"terdakwa hanya dapat dihukum menurut pasal ini, apabila ternyata bahwa kabar yang disiarkan itu adalah kabar bohong. Yang dipandang sebagai kabar bohong, tidak hanya memberitahukan suatu kabar yang kosong, akan tetapi juga menceritakan secara tidak betul tentang suatu kejadian".

Ketentuan pidana terkait penipuan yang diatur dalam KUHP dan UU ITE ini beririsan, namun juga menimbulkan dualitas pengaturan dan penanganan. Mengakibatkan ada kasus yang dapat ditangani Reskrimsus Siber dan ada yang ditangani oleh Reskrimum.

Nawawi Arief mengutip Ancel

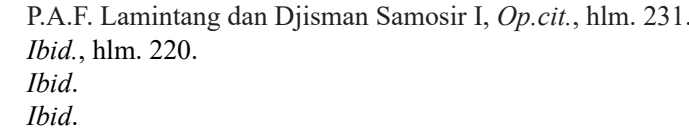


menjelaskan bahwa kebijakan hukum pidana adalah suatu ilmu sekaligus seni yang pada akhirnya memiliki tujuan praktis untuk membuat rumusan peraturan hukum positif secara baik dimungkinkan, dan untuk memberi pedoman, tidak hanya kepada pembuat undang-undang tetapi juga kepada pengadilan, yang menerapkan undangundang dan juga kepada penyelenggara atau pelaksana putusan pengadilan. ${ }^{35}$ Lebih lanjut, Sudarto menegaskan bahwa kebijakan hukum pidana berarti mengadakan pemilihan untuk mencapai hasil perundang-undangan pidana yang paling baik dalam arti memenuhi syarat keadilan dan daya guna. ${ }^{36}$ Sehingga perlu kiranya agar penanggulangan tindak pidana penipuan daring “diserahkan" kepada UU ITE sebagai umbrella provision agar tidak terjadi disparitas dan dualitas penanggulangan, yang tentu saja tujuannya adalah keadilan. Mengingat UU ITE mendeklarasikan dirinya sebagai rezim hukum baru.

\section{c. Sisi Positif Pengaturan Tindak Pidana Penipuan Daring dalam UU ITE sebagai UU yang memuat ketentuan pidana}

Sisi positif pengaturan khusus dalam UU ITE yang digunakan untuk menanggulangi tindak pidana penipuan daring ini adalah perluasan alat bukti dari pengaturan UU No. 8 Tahun 1981 Tentang Hukum Acara Pidana (KUHAP). Di dalam KUHAP, alat bukti yang sah diakui ada lima, yaitu: (a) Saksi; (b) Surat; (c) Ahli; (d) Keterangan terdakwa; dan (d) Petunjuk. ${ }^{37}$

UU ITE selain mengatur hukum materiil, juga mengatur hukum formil sebagai lex specialis. Sebagaimana diatur dalam Pasal 284 ayat (2) KUHAP bahwa dimungkinkan adanya pengesampingan aturan KUHAP oleh undang-undang pidana formil yang sifatnya lebih khusus. Di dalam Pasal 5 UU ITE diatur eksistensi alat bukti yang belum diatur oleh KUHAP, yaitu informasi elektronik dan/atau dokumen elektronik. Pasal tersebut membahasakan pengaturan ini sebagai perluasan alat bukti yang diatur oleh KUHAP, bukan penambahan. Dikatakan perluasan karena informasi elektronik dan/ atau dokumen elektronik adalah wadah yang dapat berkonten alat bukti.

UU ITE tidak menjelaskan secara eksplisit bahwa Pasal 5 ini memperluas alat bukti bahkan sampai ke tindak pidana konvensional yang diatur di dalam KUHP dan semua undang-undang di luar UU ITE ataukah hanya sekadar untuk pembuktian tindak pidana yang dilarang dan diancam pidana di dalam UU ITE saja. Namun dalam Naskah Akademik Rancangan Undangundang Tentang Informasi dan Transaksi Elektronik (RUU ITE), pembentuk undangundang menjelaskan mengenai alat bukti elektronik menggunakan contoh pembuatan dan pelaksanaan surat perkawinan, yang mana hal tersebut tidak diatur dalam UU ITE..$^{38}$ Ini berarti pembentuk undang-undang menghendaki alat bukti berupa informasi elektronik dan/atau dokumen elektronik tidak hanya berlaku untuk tindak pidana yang diancam dalam UU ITE saja.

Dalam setiap pendapat akhir fraksi

35 Mac Ancel, The Relationship Between Criminology and Politique Criminal dalam Barda Nawawi Arief, 1996, Kebijakan Legislatif dalam Penanggulangan Kejahatan dengan Pidana Penjara, Balai Penerbit Undip, Semarang, hlm.23-27.

36 Sudarto, 1981, Kapita Selekta Hukum Pidana, Alumni, Bandung, hlm. 113-114.

37 Untuk konsep alat bukti 'petunjuk' dijelaskan lebih detil pada Pasal 188 KUHAP:

1) Petunjuk adalah perbuatan, kejadian atau keadaan, yang karena persesuaiannya, baik antara yang satu dengan yang lain, maupun dengan tindak pidana itu sendiri, menandakan bahwa telah terjadi suatu tindak pidana dan siapa pelakunya.

2) Petunjuk sebagaimana dimaksud dalam ayat (1) hanya dapat diperoleh dari: keterangan saksi, surat, keterangan terdakwa.

3) Penilaian atas kekuatan pembuktian dari suatu petunjuk dalam setiap keadaan tertentu dilakukan oleh hakim dengan arif lagi bijaksana, setelah ia mengadakan pemeriksaan dengan penuh kecermatan dan seksama berdasarkan hati nuraninya.

38 Naskah Akademik Rancangan Undang-undang Tentang Informasi dan Transaksi Elektronik, Departemen Komunikasi dan Informatika Republik Indonesia: Arsip DPR RI, hlm. 38 
dalam pembahasan RUU ITE, fraksi-fraksi hanya menampakkan kegembiraan dan semuanya memahami bahwa pengesahan UU ITE merupakan angin segar bagi penegakan hukum dan pembuktian. Tidak ada yang secara eksplisit menyatakan ruang lingkup pengaturan alat bukti elektronik juga berlaku untuk tindak pidana yang diancam di undang-undang di luar UU ITE. Namun kembali dapat dilihat secara implisit bahwa kedudukan informasi elektronik sebagai alat bukti yang diatur dalam Pasal 5 UU ITE juga berlaku untuk tindak pidana yang diancam di luar UU ITE.

Implikasi yuridis dari pengakuan informasi elektronik dan/atau dokumen elektronik sebagai alat bukti, bahkan untuk tindak pidana yang diancam di luar UU ITE, adalah perbedaan penanggulangan tindak pidana penipuan daring menggunakan UU ITE dengan KUHP terdapat pada beratnya ancaman pidana. Agar UU ITE juga dapat menanggulangi tindak pidana penipuan daring secara menyeluruh, dan tidak sekadar pada yang merugikan konsumen saja, pengaturan mengenai tindak pidana penipuan daring di UU ITE perlu direformulasi. Reformulasi tersebut dapat dilakukan dengan cara:

i. Menambahkan proposisi 'penipuan' dalam Pasal 28 ayat (1), hal ini untuk memunculkan jalan dalam melakukan penafsiran sistematis terhadap pasal ini merujuk pada ketentuan mengenai tindak pidana penipuan dalam KUHP; dan

ii. Menghilangkan unsur 'konsumen' dalam formulasi pasal. Karena kerugian dalam transaksi elektronik tidak hanya terjadi pada konsumen saja, sebagaimana yang telah dijelaskan di atas; atau iii. Memasukkan unsur-unsur Pasal 378 KUHP ke dalam Pasal 28 ayat (1) UU ITE, yang mengaitkan kegiatan distribusi dan/atau transmisi informasi/ dokumen elektronik dengan perbuatan materiil yang dilarang dalam Pasal 378 KUHP.

\section{Kesimpulan}

Berdasarkan uraian di atas, dapat disimpulkan beberapa hal: Pertama, modus operandi tindak pidana penipuan daring yang dominan, berdasarkan data Reskrimsus Siber Polda Jatim adalah penipuan dengan media website, disusul dengan media email, media telephone, media sms dan media kartu kredit. Selain itu, terdapat modus operandi yang ternyata hubungan antara pelaku dan korban berada di luar produsen/penyedia jasa dengan konsumen.

Kedua, konstruksi norma dalam rumusan pasal UU ITE belum cukup untuk menjadi penanggulang semua tindak pidana penipuan daring karena kurang komprehensifnya rumusan pasal dalam UU ITE. Konstruksi Pasal 28 ayat 1 UU ITE hanya terbatas dalam mekanisme perlindungan konsumen dari penipuan, sedangkan masih banyak tindak pidana penipuan yang menggunakan modus di luar dari hubungan konsumen yang dilindungi dari produsen dan/atau penyedia jasa yang melakukan tindak pidana penipuan. Sehingga, demi menyeluruhnya penanggulangan tindak pidana penipuan daring, pasal ini perlu direformulasi. Reformulasi tersebut dapat dilakukan dengan cara menambahkan proposisi 'penipuan' dalam Pasal 28 ayat (1) agar penafsiran sistematis dapat dilakukan merujuk pada pengaturan tindak pidana penipuan dalam KUHP dan menghilangkan unsur 'konsumen' dalam formulasi pasal; atau memasukkan unsurunsur Pasal 378 KUHP ke dalam Pasal 28 ayat (1) UU ITE, yang mengaitkan kegiatan distribusi dan/atau transmisi informasi/dokumen elektronik dengan perbuatan materiil yang dilarang dalam Pasal 378 KUHP. 


\section{DAFTAR PUSTAKA}

\section{A. Buku}

Ancel, Mac, The Relationship Between Criminology and Politique Criminal dalam Barda Nawawi Arief, 1996, Kebijakan Legislatif dalam Penanggulangan Kejahatan dengan Pidana Penjara, Balai Penerbit Undip, Semarang.

Bemmelen, J.M. van, 1986, Hukum Pidana 3: Bagian khusus delik-delik khusus, Binacipta, Bandung.

Chazawi, Adami, et al., 2015, Tindak Pidana Informasi dan Transaksi Elektronik, Media Nusa Creative, Malang.

Hiariej, Eddy O.S., 2016, Prinsip-Prinsip Hukum Pidana, Edisi Revisi, Cahaya Atma Pustaka, Yogyakarta.

Ibrahim, Johnny, 2005, Teori dan Metode Penelitian Hukum Normatif, Bayumedia, Malang.

Lamintang, P.A.F., 1997, Dasar-dasar Hukum Pidana Indonesia, Citra Aditya Bakti, Bandung.

Lamintang, P.A.F., et al., 1990, Delik-delik Khusus: Kejahatan yang Ditujukan Terhadap Hak Milik dan Lain-lain Hak yang Timbul dari Hak Milik, Tarsito, Bandung. 1990, Hukum Pidana Indonesia, cetakan. III, Sinar Baru, Bandung.

Marzuki, Peter M., 2005, Penelitian Hukum, Kencana, Jakarta.

Raad, Arrest Hoge tahun 1911 dalam Andi Hamzah, 2015, Delik-delik Tertentu (Speciale Delicten) di Dalam KUHP, Edisi Kedua, Sinar Grafika, Jakarta.

Samudra, Anton Hendrik, et al, 2017, Online Transaction Fraud Methods in Indonesia and the Norm of Deterrence: The Challenges and Obstacles dalam Elfina L. Sahetapy et.al., Tackling Financial Crimes: Various International Perspectives, Genta Publishing,
Yogyakarta.

Soesilo, R., 1996, Kitab Undang-undang Hukum Pidana; Serta Komentar-komentarnya Lengkap Pasal Demi Pasal, Politeia, Bogor. Sudarto, 1981, Kapita Selekta Hukum Pidana, Alumni, Bandung.

\section{B. Internet}

Kaspersky Lab., "Consumer Security Risks Survey 2016: Connected But Not Protected", https:// press.kaspersky.com/files/2016/10/B2C_ survey_2016_report.pdf, diakses 16 Mei 2017.

Tempo online, "Penipuan Online di Indonesia Tertinggi", https://m.tempo.co/read/ news/2016/05/30/172775347/penipuanonline-di-indonesia-tertinggi, diakses tanggal 16 Mei 2017.

The Bali Times, "Trader Faces Jail over Bank Rumors", http://www.thebalitimes. com/2008/11/21/trader-faces-jail-over-bankrumors/, diakses 26 Oktober 2017.

\section{Peraturan Perundang-undangan}

Undang-undang Dasar Negara Republik Indonesia Tahun 1945.

Kitab Undang-Undang Hukum Pidana Kitab Undang-Undang Hukum Acara Pidana Undang-undang Nomor 11 Tahun 2008 Tentang Informasi dan Transaksi Elektronik (Lembaran Negara Republik Indonesia Tahun 2008 Nomor 58, Tambahan Lembaran Negara Republik Indonesia Nomor 4843).

Undang-undang No. 19 Tahun 2016 Tentang Perubahan Atas Undang-undang Nomor 11 Tahun 2008 Tentang Informasi dan Transaksi Elektronik (Lembaran Negara Republik Indonesia Tahun 2016 Nomor 251, Tambahan Lembaran Negara Republik Indonesia Nomor 5952). 